\title{
Improvisation as Atool for Improving the Teachers Knowledge In Basic Technology
}

\author{
Dr. ADU F.O; Adu E .I (M.Ed) \\ Postgraduate School College Of Education Ikere Ekiti \\ Department Of Curriculum Studies Center For Educational Technology College Of Education Ikere Ekiti
}

\begin{abstract}
This study described improvisation as a tool for improving teachers' knowledge in basic technology and the relevance of improvisation in classroom teaching and learning activities by using relevant literatures in highlighting the meaning, strategy, use, application, and goal of improvisation as an instructional tool. Using content analysis methods the application of improvisational strategies in teaching basic technology to allow for self-expression, development of higher order thinking skills and possession of more comprehensive and intimate relationship with subject matter was emphasised. Shulman's improvisational framework which advocated for the need for teachers' to master two types of knowledge namely content and curricular knowledge was explained and relevant recommendation was that the Government the teachers', learners and Government should display right attitude to improvisation in the classroom.
\end{abstract}

Keywords: Improvisation, Tool, Teachers, Knowledge, and Basic Technology.

\section{Introduction}

Improvisation is the practice of acting, dancing, singing, playing musical instruments, talking, creating artworks, problem solving, or reacting in the moment and in response to the stimulus of one's immediate environment and inner feelings.Sometimes in a classroom teaching in which a teacher discovers that a particular piece of instructional media needed for effective delivery of a lesson is not available. If the teacher is able to devise or create a suitable substitute for it, the substitute is an improvised instructional media. Improvisation as a concept can be defined as a technique of originating a totally new tool, instrument, material, devise or modifying existing ones for serving a particular function. For the teacher to be able to improvise, he must be innovative, resourceful and creative in both thinking and manipulative dexterity (John, 2009).

Ajewole,(1998), defined improvisation as devise and construction of alternative instructional media as substitute to the manufactured ones. This can result in the discovery of new thought patterns, practices, new structures or symbols, and new ways to act. The invention cycle is most effective when instructional designers and developers have a clear insight and manipulative skills needed for the development of any improvised media.

Improvisation is applicable to almost all facet of knowledge like arts, science, education, medical sciences, engineering and non-academic spheres. The process of teaching and learning requires a good deal of improvisation since it touches the cognitive, affective and psycho motive domains of learners'. When improvisation is utilised in a small group collaborative teaching and learning activities in a learner-centered environment, it can be a powerful teaching tool. Research evidence demonstrated that it can promote spontaneity, intuition, interactivity, inductive discovery, attentive listening, non verbal communication, adlibbing, role-playing, risk-taking, team building, creativity and critical thinking (Crossan, 1998, Moshavi, 2001, Sawyer, 2004, Spolin, 1999).

\section{Literature Review}

\section{Strategies of Improvisation}

There are seven strategies of improvisation:

1.Trust: In order for a group of teachers to be successful and productive, the members of the group, referred to as "Players", must trust one another.

2.Acceptance: This is the "Golden Rule" of improvisation (Gessell, 1997). Teachers must be willing to accept a new idea in order to explore its possibilities. Teachers must offer to improvise using ideas, words or movement and must build on it. In other words, teachers must say yes, accept the offer, build on it, contribute and discover new ideas. It is this process that harnesses the power of collaboration. The brainstorming that occurs can lead to innovative solutions (Koppett, 2001).

3.Attentive listening: Teachers must be aware of the partners with whom they are co-creating in order to increase their understanding of each other and to be able to communicate effectively.

4. Spontaneity: This allows teachers to initiate words and actions, building trust with the other teachers. This enhances co-creation in the moment, without the opportunity to revise (Keefe, 2002). 
5.Storytelling: This strategy often results in memorable content, when teachers develop the ability to create a story on their dialogue.

6. Nonverbal communication: This involves the use of facial expressions and body language to help communicate attitude, character, and trustworthiness.

7.Warm-ups: They are strategies that provide opportunities to develop trust and safe environments, where the teachers can feel free to explore the world of improvisation. These activities focus on changing teachers into an improvisational mode to allow them to improvise verbally and physically (Koppett, 2001).

\section{The Use of Improvisational Strategies in Classroom Activities.}

Improvisational strategies are typically viewed as an alternative to the ready-made instructional media and it has also taken on varieties of creative genres, including storytelling, pantomime, music poetry and comedy (Atkins, 1993, Book, 2002, Diggles, 2004, Gwinn \& Halpern, 2003, Lynn, 2004, Polsky, 1997, Spolin, 1999). There are four major instructional reasons for using improvisation in the classroom:

(1) It is consistent with the characteristics of the current genres of the learners known as "Net Generation" (Carlson, 2005, Junco \& Mastrodicasa, 2007, Oblinger \& Oblinger, 2006a, Palfrey \& Gasser, 2008, Tapscott, 1999, 2009, Howe \& Strauss, 2000). This generation has grown up with the technology, especially their desire to learn by inductive discovery, experiential experiences and collaborative teaching.

(2) It taps into learners multiple and emotional intelligence.

(3) It foster collaborative learning by helping to build trust, respect, and team spirit as well as listening, verbal and nonverbal communication, ad-libbing, role-playing, risk-taking and storytelling skills (Berk, \& Trieber, 2009).

(4) It promotes deep learning through the active engagement with new ideas, concepts or problems, linking the activities or tasks to prior learning, applying the content to real-life applications, and evaluating the logic and evidence presented.

Improvisation involves teachers creating a physical reality through manipulative actions and emotions and at the same time ensuring that it soothes the learners learning experiences and Spolin, (1999) stated that the goal of improvisation is to "solve a problem". The power of improvisation lies in being active at all times. A major concept is that the point of concentration requires attention to the problem rather than to the individuals addressing the problem.

\section{Application of Improvisational Strategies, in the Teaching of Basic Technology.}

Creativity and improvisation have been an important role in teaching Basic Technology (Azzara, 2002). It indicates that improvisation happens when an individual has internalized a Basic Technology concept and is able to understand and to express Basic Technology ideas spontaneously. He added that there are important factors to consider in defining improvisation, such as the process of expressing Basic Technology thoughts and emotions, creating Basic Technology within certain structures previously learnt, and producing Basic Technology discourse. In researching the application of improvisation within the context of Basic Technology, Azzara stated that improvisation allows self-expression, and to develop higher order thinking skills, and possess a more comprehensive and intimate relationship with Basic Technology.

It is important to develop improvisation in the community, develop an atmosphere where improvisation, spontaneity and interaction are nourished, understand improvisation as a way of life and not just an activity, believe that improvisation may be developed and that all teachers have the potential to improvise, observe that improvisation can affect other Basic Technology skills, and incorporate a model to develop improvisation skills that will help teachers as well as students. In an attempt to find an answer on how teachers can improvise, Kenny \& Gellrich (2002) suggested two strategies: transcendence and deliberate practice.

Transcendence, as stated by Kenny \& Gellrich (2002) is a state of consciousness that reaches beyond the knowledge accumulated within you, whereas the primary objective of deliberate practice is to stimulate the development of improvisation skills through the bases of acquired knowledge. It is important that group activities complement individual practice. Although individual practice is beneficial to the development of technical and theoretical principles, improvisation emphasizes more collective participation.

Creative improvisations generally occur in a collective participatory atmosphere as opposed to an individualized teaching and learning context. The ability of teachers to react and create Basic Technology materials or media through unpredictable dynamics and variables is one of the most distinct aspects of improvisation (Lidia \& Sara, 2010).

\section{The Application of Teachers Knowledge on Improvisation.}

To teach learners according to standards, teachers need to understand improvisation and strategies deeply and flexibly so they can help learners create useful cognitive maps, relate one idea to another, and address misconceptions. Teachers need to see how improvisation connects across fields and to everyday life. 
This kind of understanding provides a foundation for improvisational content knowledge that enables teachers to make ideas real to the learners' (Shulman, 1987). He introduced the phrase improvisational content knowledge and sparked a whole new wave of scholarly articles on teachers' knowledge of their subject matter and the importance of this knowledge for successful teaching.

In Shulman's improvisational framework, teachers need to master two types of knowledge:

(a) content, also known as deep knowledge of the subject itself, and

(b) knowledge of the curricular development.

Content knowledge encompasses what Shulman, (1992) called structure of knowledge, theories, principles, and concepts of a particular discipline, while the knowledge of the curricular development is the awareness of the rudiments and wherewithal of the use and administration of the curriculum for the designing and adequate planning of the contents of curriculum for teaching and learning processes.

\section{Goals of Improvisation in Teaching and Learning Processes}

Learners generally remember twenty per cent $(20 \%)$ of what they hear, thirty per cent $(30 \%)$ of what they see, fifty per cent $(50 \%)$ of what they see and hear, ninety per cent $(90 \%)$ of what they see and do. This illustration is more evident in our learners today where their mode of analysing football matches or film to their colleagues shows how powerful and effective their visual experiences are to their verbal experience (Osho, 2011).

This should have been an advantage to their academic achievement but the opposite is the case. There is the need, therefore, in tapping and building upon this gain of visual experiences through the world of improvisation. Education in general can only be successful with reasonable availability and proper selection of equipment, facilities and supplies. The fact remains that it is virtually impossible to purchase or make all the equipment, facilities and supplies required for sound and quality education available, especially in this part of the world. This makes it imperative for teachers to think of how best to make use of their manipulative skills to improvise so as to achieve their lesson objective at least to a reasonable extent. Instructional media ensure that the learners see, hear, feel, recognise and appreciate as they learn, utilising the five senses modalities at the same time (Lidia \& Sara, 2010).

When the real instructional media and equipment are not available, improvisation takes their place. This is to enhance the teaching and learning processes as well as make the expensive nature of scientific equipment, the difficulty experienced in procuring them as well as the excruciating and persistent problem of inadequate of funds irrelevant in achieving the instructional objective. It is a fact that non provision of real media and equipment have all combined to worsen the teaching of science and technology education in schools(Kenny \& Gellrich, 2002).

But with well packaged and relevant improvisation, the arbitrary and complete abstract of the subject matter in the face of the learner is significantly reduced to lend credence to the importance and essence of improvisation where and when the real instructional media are not on hand. Improvisation can be described as substitute: To make a substitute for an item, out of the material that can easily be sourced for or available at the time. Improvisation and fabrication can be explained as composing a careful selection and use of media as an alternative means of complementing the existing or otherwise instructional media and equipment in schools (Osho, 2011).

Through improvisation, learners' attention are captured and retained for the better part of the lesson. Since they serve as educational media, students' interest in science and technology education is stimulated, meaningful and interesting. Learning is more permanent and there is development of skill in the psychomotor domain. The need for improvisation becomes essential where, as the case is in Nigeria, there is inadequate capital to procure the real media and equipment. It is also necessary when population outweighs what is available because of the insufficient funding in education(Azzara, 2002).

Due to gross inadequacy of media and equipment meant to enhance the effectiveness of science and technology education in the area of teaching and learning, many teachers develop wrong attitude towards the preparation and use of improvised and fabricated local equipment and materials. The wrong attitude is reflected in the teacher's persistent preference for the moribund chalk and talk method to other forms of contemporary method of teaching. Our environment is richly endowed with materials that can be employed in the school to make teaching real and lively. Efforts should therefore, be stepped up to provide improvisation and fabrication material very abundant in our schools more so that emphasis nowadays is placed on relating what is taught to the worldview of the learners. It is therefore, important to improvise and fabricate for the following reasons: To provide to learners a cognitive bridge between abstraction and reality of knowledge, to widen the scope of inquiry, to develop in learners the necessary process and practical skill and to provide materials in abundant quantities thereby enabling learners work independently (Spolin, 1999).

The basis for success in classroom teaching is resourcefulness. To be able to improvise requires being resourceful and creative. Certain steps to be followed for effective improvisation and fabrication of material 
include: Identify the item to be improvised and fabricated, understanding the basic principles involved in its working, Design and draw a rough sketch of the item, Make a list of the materials needed, Construct the item according to the given procedure to produce the prototype, Test and evaluate through use, Re-design if need be and Mass-production if possible and necessary (Berk, \& Trieber, 2009).

For learners and teachers to derive maximum benefits from improvised and fabricated media and equipment, the teacher must have adequate knowledge of the particular subject matter. It is equally important for the teacher to have a thorough understanding of the learning process in addition to possessing a good knowledge of available improvised media and equipment. The environment is richly endowed with material resources that could be utilized for improvisation (Koppett, 2001).

Teachers need to harness the opportunity provided by the abundance of resources to produce variety of materials that can bring about concrete and meaningful learning. Most of the raw materials for improvisation can easily be obtained from the home, hardware shop, radio-repair shop, automobile repair shop, food market, the school laboratory, school, office, bicycle repair shop, and the locality. Improvised apparatus is often more effective as a teaching tool as it is easier to see and understand the principle involved when the parts that make up the apparatus are exposed and not hidden (Osho, 2011).

\section{Conclusion and Recommendation}

The idea of adopting improvisation as an instructional tool is very important to teachers' day to day teaching and learning activities and in order to make the process of instruction interesting, active and participatory, teachers' need adequate knowledge about it. The process of improvisation gives teachers' the knowledge of creativity, manipulative skills, and critical thinking. Improvisation helps in saving cost of looking for ready made instructional media which are more costly. It encourages self-reliance and a feeling of confidence during instruction delivery. It provides employment opportunities for youths that are unemployed in the community (Ajewole, 1998). It saves time during instruction delivery. It also allows the teachers' and learners' to display their skills of creativity in teaching and learning activities for better understanding and assimilation of concepts being taught in the classroom. Improvisation is good so the teachers', learners', and Government should display right attitude to the idea in the classroom.

\section{References}

[1]. Ajewole, K. (1998). Improvisation of educational media. Lagos: Retrieved from, http://edutech212.wordpress.com/2013/06/25/improvisation-of-educational- media 29/6/13.

[2]. Atkins, G. (1993). Improve: A handbook for the actor. Portsmouth, NH: Heinemann Drama.

[3]. Azzara, C.D. (2002). Improvisation in Colwel, Richard (ed), The New Handbook of Research on Music Teaching and Learning: A Project of the Music Educators National Conference, Oxford :University Press.

[4]. Berk, R.A \& Trieber, R.H. (2009). Whose classroom is it, anyway ? Improvisation as a teaching tool. Journal on Excellence in College Teaching, 20 (3), 29- 60.

[5]. Book, S. (2002). Book on acting: Improvisation technique for the professional actor in film, theater and television. Los Angeles: Simon- James Press.

[6]. Carlson, S. (2005). The net generation goes to college. The Chronicle of Higher Education, 52 (7), p A34.

[7]. Crossan, M.M. (1998). Improvisation in action. Organisation science, 9 (5), 593- 599.

[8]. Diggles, D. (2004). Improve for actors. New York: Allworth Press.

[9]. Gessell, I. (1997). Playing along 37 group activities. Duluth, MN: Whole Person Associates.

[10]. Gwinn, P. \& Halpern, C. (2003).Group improvisation: The manual of ensemble improve games. Colorado Springs, Co: Meriwether.

[11]. Howe, N. \& Strauss, W. (2000).Millenials rising: The next great generation. New York: Vintage Books.

[12]. John, A. (2009). Improvisation in rehearsal. London: Nick Hern Books. ISBN 978- 1-85459-523-2.

[13]. Junco, R. \& Mastrodicasa, J. (2007).Connecting to the net generation: What higher education professional need to know about todays student.

[14]. Washington D.C: Student Affairs Administrators in higher education (NASPA).

[15]. Keefe, J.A. (2002). Improve yourself. Business spontaneity at the speed of thought. Hoboken, NJ: Wiley.

[16]. Kenny, J.B. \& and Gellrich, M. (2002). Improvisation in Parcutt, Richard \& Mcpherson, Gary (ed). The Science and Psychology of Music Performance: Creative Strategies for Teaching and Learning. Oxford: University Press.

[17]. Koppett, K. (2001). Training to imagine: Practical improvisational theater techniques to enhance creativity, teamwork, leadership and learning. Sterling, VA: Stylus.

[18]. Lidia, M. \& Sara, C. (2010).Exploration and Improvisation: The use of creative strategies in instrumental teaching. Portugal: International Journal for Cross-Disciplinary Subjects in Education (IJCDSE), Volume 1, Issue 4.

[19]. Lynn, B. (2004). Improvisation for actors and writers : A guidebook for improve lessons in comedy. Colorado Springs, Co: Meriwether.

[20]. Moshavi, D. (2001). Yes and...: Introducing improvisational theater techniques to the management of classroom. Journal of Management Education, 25 (4), 437- 449.

[21]. Oblinger, D. \& Oblinger, J, (2006a).Is it age or IT : First steps toward understanding the net generation.In D.C. Oblinger \& J.L Oblinger (Eds.)

[22]. Educating the net generation.EDUCAUSE. Retrieved November 14, 2006, from www.educause.edu.

[23]. Osho, L. (2011). Need for improvisation in classroom teaching. Lagos:Retrieved from :http://odili.net/news/source/2011/jun/20/802.html on 29/6/13.

[24]. Palfrey, J. \& Gasser, U. (2008).Born digital: Understanding the first generation of digital natives. New York: Basic Books.

[25]. Polsky, M.E. (1997). Let's improvise: Becoming creative, expressive and spontaneous through drama (3 ${ }^{\text {rd }}$ ed.). Upper Saddle River, NJ: Prentice-Hall. 
[26]. Sawyer, R.K. (2004).Creative teaching: Collaborative discussion as disciplinedimprovisation. Educational Researcher, 33 (2), 1220.

[27]. Shulman, L. (1992). Ways of seeing, ways of knowing, ways of teaching, ways of learning about teaching. Journal of curriculum studies, 28, 393-396.

[28]. Shulman, L. (1987). Knowledge and teaching: Foundations of the new reform.Harvard Educational Review, 57(1), 1-22.

[29]. Spolin, V. (1999). Improvisation for the theater: A handbook of teaching and directing techniques ( $3^{\text {rd }}$ ed). Evanston, IL. Northwestern University Press.

[30]. Tapscott, D. (1999).Growing up digital: The rise of the net generation. New York: McGraw-Hill.

[31]. Tapscott, D. (2009). Growing up digital: How the net generation is changing your world. New York: McGraw-Hill. 